\title{
Niemann-Pick hastalığı tip A ve tip B: İki olgu sunumu
}

\author{
Niemann-Pick disease type A and type B: A report of two cases
}

Pelin ZORLU, Şit UÇAR, Neşe YARALI, Fulya DEMİÇEKEN

\section{ÖZET}

Niemann-Pick hastalığı, belirli dokularda, özellikle retiküloendotelyel hücrelerde, sfingolipidlerin biriktiği, konjenital lipidoz grubundan otozomal resesif kalıtılan bir hastalıktır. Klinik fenotip olarak akut neonatal formdan geç başlangıçlı erişkin forma kadar aralığı oldukça değişkendir. Karaciğer ve dalak büyüklüğü şikayetiyle kliniğimize başvuran Niemann-Pick hastalığı tip A ve tip B tanıları alan iki hasta sunuldu.

Anahtar kelimeler: Lipid depo hastalığ Sfingomyelinaz.

\section{ABSTRACT \\ Niemann-Pick disease is an autosomal recessively inherited group of congenital lipidoses in which sphingolipids accumulate in certain tissues, especially reticuloendothelial cells. The clinical phenotype is extremely variable, ranging from an acute neonatal form, to an adult late-onset form. We presented two patients who admitted to our clinic with hepatosplenomegaly and diagnosed as Niemann-Pick disease type A and type B.}

Key words: Lipid storage disease, Niemann-Pick disease, Sphingomyelinase.
Pelin Zorlu, Şit Uçar (四)

Çocuk Sağlı̆̆ı ve Hastalıkları, Dr. Sami Ulus Kadın Doğum, Çocuk Sağlığı ve Hastalıkları Eğitim ve Araştırma Hastanesi, Ankara, Türkiye e-mail: situcar@mynet.com

Neşe Yaralı

Çocuk Hematoloji, Dr. Sami Ulus Kadın Doğum, Çocuk Sağlığı ve Hastalıkları Eğitim ve Araştırma Hastanesi, Ankara, Türkiye

Fulya Demirçeken

Çocuk Gastroenteroloji, Dr. Sami Ulus Kadın Doğum, Çocuk Sağlığı ve Hastalıkları Eğitim ve Araştırma Hastanesi, Ankara, Türkiye

Gönderme/Submitted: 12.09.2013

Kabul/Accepted: 01.10 .2013

\section{Giriş}

Niemann-Pick hastalığı (NPH), sfingomyelinaz enzim eksikliğine bağlı olarak vücudun çeşitli organlarında, özellikle retiküloendotelyal sistem ve santral sinir sisteminde, intraselüler sfingomyelin ve kolesterol birikimi ile karakterize, otozomal resesif geçişli, nadir görülen bir lizozomal lipid depo hastalığıdır[1]. Genetik, klinik ve biyokimyasal heterojeniteye sahip hastalığın altı tipi tanımlanmıştır: Tip A-Akut nöronopatik form, Tip B-Kronik visseral form, Tip C-Kronik nöronopatik form daha iyi tanımlanmış formlardır. Tip A tüm hastaların $\% 85^{\prime}$ ini oluşturur [1,2].

Niemann-Pick hastalığında sıklıkla nörolojik ve gastrointestinal sistem bulguları, büyüme-gelişme geriliği, göz bulguları, nadiren de solunum sistemi, cilt ve kardiyak bulgular görülür. Tanı, sfingomyelinaz aktivitesinin tespiti ve Niemann-Pick hücrelerinin kemik iliği incelemesinde gösterilmesi ile konur $[1,3]$. Burada NPH tanısı alan iki farklı tipte (tip A ve B) olgu sunuldu.

\section{Olgu Sunumu}

Olgu 1: 15 aylık erkek hasta, karın şişliği, yürüyememe, konuşamama şikayetleriyle başvurdu. Öyküsünden aralarında üçüncü derece akrabalık olan anne babanın ikinci çocukları olarak, miadında, hastanede, 3800 gr olarak, normal yol ile doğduğu, iki kez pnömoni nedeniyle hastanede yattı̆̆g öğrenildi. Kardeş ölümü ve ailede benzer hastalık öyküsü yoktu. Bir aylıkken karın şişliği başlamış, altı aylıkken karaciğer ve dalakta büyüme farkedilmiş ve gittikleri merkez tarafından tetkikleri yapılmış; alfa-1 antitripsin, ter testi, viral serolojiler, immünglobulin M-AG-E, göz muayenesi, kemik iliği aspirasyonu incelemesi, idrar ve kan aminoasitleri ve tandem mass incelemeleri normal bulunmuş. Karaciğer biopsisinde hepatositlerde sekonder lizozomlar çok sayıda, geniş ve birleşmiş olarak izlenmiş ve hepatositlerde yoğun lipid damlacıkları görülmüş. Nöromotor gelişim öyküsünde; dört aylıkken 
anneyi tanıdığ oturma ve yürümesinin hala olmadığı öğrenildi.

Fizik incelemesinde, genel durumu iyi, vücut ağırlığı 8200 gr $(<3$ p), boy-baş çevresi ve vital bulguları normal bulundu. Gözde makulada Japon bayrağı görünümü mevcut ve optik disk sınırları silik olarak izlendi. Karaciğer kot kenarını $12 \mathrm{~cm}$, dalak $11 \mathrm{~cm}$ geçiyor ve sert olarak palpe ediliyordu. Nörolojik muayenesinde başını tutuyor, oturamıyor, kas tonusu ve derin tendon refleksleri artmış bulunurken diğer sistem muayeneleri normal bulundu.

Laboratuvar tetkiklerinde, hemoglobin $12,5 \mathrm{gr} / \mathrm{dL}, \mathrm{MCV}$ $70 \mathrm{fL}$, lökosit sayısı $11,2 \times 10^{3} / \mathrm{mm}^{3}$, trombosit sayıs1 $168 \times 10^{3} / \mathrm{mm}^{3}$, aspartat aminotransferaz (AST) $275 \mathrm{U} / \mathrm{L}$, alanin aminotransferaz (ALT) $120 \mathrm{U} / \mathrm{L}$, total protein $5.9 \mathrm{~g} /$ $\mathrm{dL}$, albümin $3,5 \mathrm{gr} / \mathrm{dL}$, kolesterol $168 \mathrm{mg} / \mathrm{dL}$ ve trigliserid $495 \mathrm{mg} / \mathrm{dL}$ bulundu. Böbrek fonksiyon testleri, serum elektrolitleri, bilirübinleri, alkalen fosfataz, tam idrar tetkiki, protrombin zamanı (PT), aktive parsiyel tromboplastin zamanı (aPTT) ve arteriyel kan gazları normal bulundu. Periferik kan yaymasi incelemesinde patoloji yoktu. Uzun kemik grafilerinde yaygın osteopenik görünüm, medullada genişleme ve kortekste incelme izlendi. Transfontanel ultrasonografi ve ekokardiyografisi (EKO) normal bulundu.

Elektroensefalografi (EEG)'de yavaşlama ve parsiyel epileptiform bozukluk tespit edildi. Abdominal ultrasonografide karaciğerde grade-I ekojenite artışı ve diffüz hepatosplenomegali izlendi. Kemik iliği aspirasyonunda Niemann-Pick köpük hücreleri görüldü (Şekil 1). Beyin manyetik rezonans (MR) incelemesinde, hemisferik kortikal sulkuslarda hafif genişleme ve serebral beyaz cevherde bilateral dismyelinizasyona ait olabileceği düşünülen anormal hiperintens alanlar tespit edildi. Sfingomyelinaz enzim ativitesi $0(52-173) \mathrm{nm} / \mathrm{s} / \mathrm{mgp}$ bulunarak NPH tanısı kondu. Mutasyon analizi yapılamadı. Çocuk Metabolizma ve Gastroenteroloji bölümlerinde takibe alınan hasta, destek tedavisi ile izlenmektedir.

Olgu 2: Alt1 aylık kız hasta, bir ay önce pnömoni nedeniyle yattı̆g büyüklüğü ve karaciğer fonksiyon testlerinde bozukluk nedeniyle hastanemize sevk edildi. Öyküsünden hastanede, miadında, normal yolla, 3400gr doğduğu, hemen ağladığı, siyanozunun olmadığı, altı aylık olana kadar iki kez pnömoni nedeniyle hastanede yattığı, anne sütü ve son iki aydır ek gıda aldığı, nöromotor gelişiminin normal olduğu öğrenildi. Anne ve baba arasında birinci derece akrabalık olan hastanın iki sağlıklı kardeşi olduğu, ölen kardeşinin olmadığı ve ailede amcanın üç çocuğunun karaciğer ve dalakta büyüme ile seyreden bir hastalık nedeniyle bir yaş civarında öldüğü öğrenildi.

Fizik muayenesinde genel durumu iyi, bilinç açık, vücut ağırlığı 5800gr (3-10p), boy- baş çevresi ve vital bulguları normal bulundu. Göz muayenesinde makulada Japon

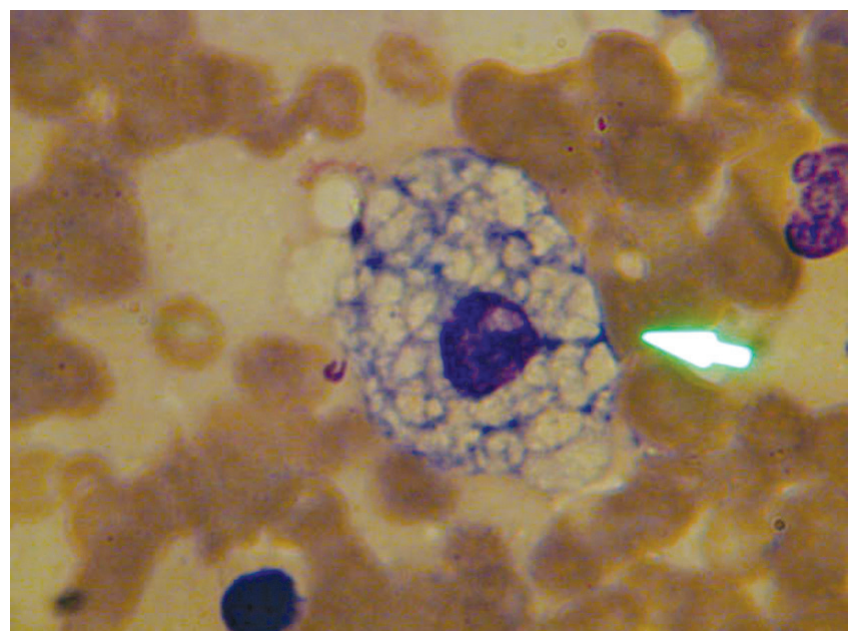

Şekil 1. Olgu 1' in kemik iliği aspirasyonunda Niemann-Pick hücresi.

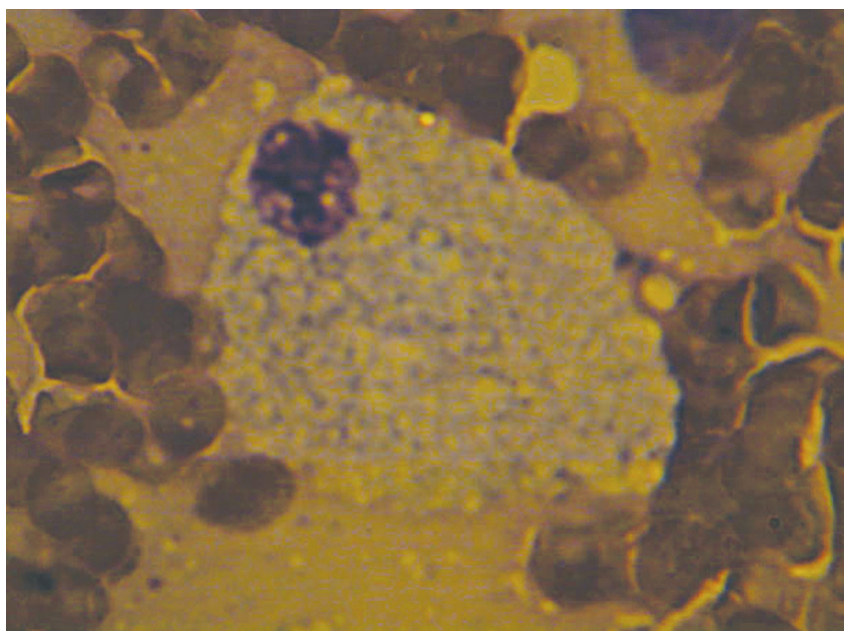

Şekil 2. Olgu 2’ nin kemik iliği aspirasyonunda Niemann-Pick hücresi.

bayrağ 1 görünümü tespit edildi. Batın muayenesinde karaciğer $8 \mathrm{~cm}$ ve dalak $7 \mathrm{~cm}$ sert kenarlı olarak palpe edildi. Diğer sistem muayene bulguları normal bulundu.

Laboratuvar tetkiklerinde, hemoglobin $11,7 \mathrm{gr} / \mathrm{dL}, \mathrm{MCV}$ $77 \mathrm{fL}$, lökosit sayısı $20,6 \times 10^{3} / \mathrm{mm}^{3}$, trombosit sayıs1 $400 \times 10^{3} / \mathrm{mm}^{3}$, AST $894 \mathrm{U} / \mathrm{L}$, ALT $324 \mathrm{U} / \mathrm{L}$, kolesterol 212 $\mathrm{mg} / \mathrm{dL}$ ve trigliserid $362 \mathrm{mg} / \mathrm{dL}$ bulundu. Böbrek fonksiyon testleri, serum elektrolitleri, bilirübinleri, alkalen fosfataz, albümin, tam idrar tetkiki, PT, aPTT, arteriyel kan gazları ve uzun kemik grafileri normal bulundu. Abdominal utrasonografide diffüz hepatosplenomegali tespit edildi. Hepatit A, B ve C, sitomegalovirüs, Epstein-Barr virüs, toksoplazma, rubella, HIV ve herpes virüs serolojileri, idrar ve kan aminoasitleri, tandem mass incelemesi, salmonella ve brusella tetkikleri normal bulundu. Transfontanel ultrasonografi, EEG, EKO ve beyin MR incelemeleri normal bulundu. Kemik iliği aspirasyonu incelemesinde Niemann-Pick hücreleri görüldü (Şekil 2). Sfingomyelinaz 
enzim ativitesi 0 (52-173) nm/s/mgp bulunarak NPH tanıs1 kondu. Mutasyon analizi yapılamadi. Takibe alınan hasta 18 aylıkken değerlendirildiğinde karaciğer 9-10cm, dalak inguinalde sert olarak palpe ediliyordu. Hastanın iki yaşına geldiğinde yapılan nörolojik muayenesi ve gelişimsel testleri normal olarak bulundu.

\section{Tartışma}

Niemann-Pick hastalığı, otozomal resesif geçen, sfingomyelin ve kolesterolün santral sinir sistemi ve diğer organlarda birikmesiyle karakterize bir lizozomal lipid depo hastalığıdır. Hastalık ilk kez Niemann tarafından tanımlanmış ve hastalığın diğer benzer durumlardan ayırımını Pick sağlamıştır. Crocker ve Farber ise sınıflandırmayı yapmışlardır [3]. Hastalıkta sfingomyelini, seramid ve fosforilkoline parçalayan asit sfingomyelinaz (ASM, sfingomyelin fosfodiesteraz) enziminde eksiklik veya gen mutasyonları vardır. ASM eksikliği, retiküloendotelyal sistemde sfingomyelinin ve ikincil olarak da kolesterolün yoğun depolanmasına neden olur. Başlıca tutulan organlar karaciğer, dalak, beyin, kemik iliği ve akciğerdir $[1,3,4]$. Hastalığın kliniği oldukça değişkendir ve altı ayrı formu tanımlanmıştır. Köpük hücre infiltrasyonu ve organomegali bütün formlarda yaygındır. Ancak, nörolojk bulgular tip A ve C'de belirginken, tip B ve E'de görülmez [4,5].

Kliniğimize hepatosplenomegali nedeniyle başvuran her iki olgunun da aminotransferazları yüksek, sentez fonksiyonları, serum elktrolitleri ve böbrek fonksiyonları normal bulundu. Ultrasonografilerinde diffüz hepatosplenomegali tespit edildi. Etyolojiye yönelik viral çalışmaları, metabolik taramaları, immünglobülin değerleri, alfa-1 antitripsin düzeyleri normal bulundu. Anne-baba arasında akrabalık öyküsü olan, karaciğer ve dalağı sert ve büyük tespit edilen ve göz muayenesinde makülada Japon bayrağ 1 görünümü olan olgularda lipid depo hastalığg düşünülerek kemik iliği aspirasyonu incelemesi yapıldı. Her iki olguda da Niemann-Pick köpük hücreleri görüldü. Çalışılan sfingomyelinaz enzim aktivitelerinin tamamen yokluğu nedeniyle NPH tanısı konuldu.

NPH, Aşkenazi yahudilerinde sık görülür. Başlangıç yaşı ve mortalite zamanı değişkendir. NPH tip A, en sık görülen formdur ve fatal seyirlidir. Bu formda hayatın ilk beş ayında ilk bulgular başlar. Genellikle ilk bulgu hepatosplenomegalidir. Beslenme güçlüğü, karın şişliği, erken motor fonksiyonlarda ilerleyici gerilik, maküler dejenerasyon ve konvülziyonlar gelişir. Yaşamın ilk iki-üç yılında kaybedilirler. Sfingomyelinaz enzim aktivitesi tama yakın azalmış veya hiç yoktur $[4,6]$. Olgu 1, erken yaşta başlayan belirgin hepatosplenomegali, gelişme geriliği, nörolojik tutulum ve sfingomyelinaz enzim aktivitesinin tamamen yokluğu nedeniyle NPH tip A tanısı aldı.
NPH tip B, enzim aktivitesinin yokluğu yönüyle tip A'ya benzer ancak klinik farklıdır. Erken çocukluk döneminde karın şişliği şikayetleriyle başlayabilir veya adolesan dönemde de başlangıç olabilir. Tekrarlayan akciğer enfeksiyonu ve organomegali görülürken santral sinir sistemi bulguları görülmez. Akciğer tutulumu nedeniyle oksijen gereksinimi olur. Transaminazlarda artış, hiperlipidemi ve kardiyovasküler sistem tutulumu ve makular bozukluklar eşlik edebilen diğer bulgulardır [7-9]. Erken dönemde hepatosplenomegali tespit edilen, iki kez pnömoni öyküsü olan, nörolojik tutulumun olmadığ1, transaminazlarda artışın ve hiperlipideminin eşlik ettiği ve enzim aktivitesinin tamamen kaybolduğu olgu 2, NPH tip B olarak değerlendirildi. Siklıkla ilk bulgular erken çocukluk döneminde başlamakla birlikte NPH tip B'nin bebeklik döneminde de nadir olarak başlayabildiği bildirilmiştir $[7,8]$.

NPH tip C, daha nadir görülen formudur. Okul çocukluğu döneminde başlangıç sıktır ancak, erken bebeklikten erişkin yaşa kadar herhangi bir dönemde ortaya çıkabilir. Hastalar ilk iki yaşa kadar genellikle normal gelişim gösterirler. NPH tip A kadar belirgin olmayan hepatosplenomegali vardır $[1,5,10]$. Ekzojen kolesterolün hücre içi metabolizmasındaki bir hata nedeniyle esterleşmeyen kolesterolün lizozomlarda birikmesi ile karakterizedir. Sfingomyelinaz enzim aktivitesi normal veya normale yakın bulunur. Klinik değişken olmakla birlikte klasik fenotip hepatosplenomegali, vertikal supranükleer oftalmopleji, ilerleyici ataksi, distoni ve demans ile karakterizedir. Ölüm yaşı da değişkenlik göstermektedir [5-10].

Büyüme gelişme geriliği NPH'da sık olarak izlenen bir bulgudur ve enzim replasman tedavisi ile düzeleceği ümit edilmektedir [4-11]. Gözde makulada kiraz kırmızısı (Japon bayrağ 1 görünümü), maküler halo ve korneal opasifikasyon görülebilir $[4,6,12]$. Sfingolipidoz grubu hastalıklardan özellikle NPH ve Tay-Sacs hastalığında görülen kiraz kırmızısı her iki olgumuzun oftalmoskopik muayenesinde de tespit edildi. NPH tip A'da daha sik ve tip B'de nadir görülen kiraz kırmızısı, bazen başlangıçta olmayıp daha sonraki muayenelerde izlenebilmektedir $[4,12]$. İlk olgunun daha önceki muayenesinde makulanın normal değerlendirilmesi bu durumla ilişkili olabilir. NPH'nın daha nadir görülen bulguları ise ciltte nodüler ksantom, akciğerde intertisiyel pulmoner infiltrasyon ve koroner kalp hastalığıdır $[2,6]$.

Kemik iliği incelemesinde petek şeklinde vakuollü köpük hücreleri (Niemann-Pick hücreleri) deniz mavisi histiyositlerin görülmesi tanıyı destekler. Deniz mavisi histiyositler, stoplazmalarında maviye boyanan oksitlenmiş lipid birikimi olan makrofajlardır ve lösemi, myelodisplastik sendrom ve Gaucher hastalığında da görülebilirler $[2,4,13]$.

Cilt fibroblastları ve periferik kan lökositlerinde sfingomyelinaz aktivitesinin tama yakın yokluğu tip A ve B'de sözkonusuyken, tip C ve D'de normal veya normale 
yakındır $[4,6,10]$. Her iki olguda da sfingomyelinaz aktivitesinin hiç olmadı ̆̆ görüldü.

NPH tip A ve B'de hepatosplenomegali ve eşlik eden transaminaz yüksekliğine rağmen karaciğerin sentez fonksiyonlarının normal olduğu bildirilmiştir $[6,9]$. Her iki olguda da albümin ve protrombin zamanı normalken transaminazlarda yükseklik tespit edildi. NPH tip A ve B'de özellikle Aşkenazi yahudilerinin \%90' dan fazlasında kromozom 11p15'te SMPD1 mutasyonu tanımlanmıştır $[6,10]$. NPH'nın amniyosentez ve koryon villus biopsisi ile prenatal tanısı mümkündür $[4,6,10]$. Olgularda mutasyon analizi çalışılamadı. Her olgunun ailesine de genetik danışma önerildi.

Beyin MR incelemesinde, periventriküler beyaz cevher değişiklikleri, hiperintens alanlar izlenebilir [2,6]. Nörolojik tutulumun olduğu ilk olguda beyin MR incelemesinde beyaz cevherde hiperintens alanlar izlenirken, nörolojik tutulum olmayan ikinci olguda beyin MR normal bulundu. NPH'de, EEG' de yaygın yavaşlama ve epileptik aktiviteler izlenebilir [2]. Olgu 1' in EEG' sinde yavaşlama ve parsiyel epileptik aktiviteler izlendi. Akciğer tutulumu tip A ve B'de görülebilir ancak, tip B'de daha sıktır. Radyolojik olarak yaygın retikülonodüler infiltrasyon izlenebilir. NPH tip B'de mortalite ile morbiditenin ana sebebi akciğer tutulumudur $[6,8]$. Mendelson ve arkadaşları NPH olan ve solunum sistemi bulguları izlenen 53 olgunun \%90'1nda intertisiyel akciğer hastalığı tespit etmişlerdir [14]. Her iki olguda da pnömoni geçirme öyküsü olmasına karşlık direkt radyografide akciğerler normal bulundu.

NPH için spesifik bir tedavi yöntemi yoktur. Genel olarak destek tedavisi uygulanan tip A, 2-3 yaşlarında ölümle sonuçlanmaktadır. Tip A ve tip C hastalarında tedavi yaklaşımı ağır nörolojik hasarın önlenmesine yöneliktir $[6,10]$. NPH tip B hastalarının az bir kısmında allogenik kemik iliği transplantasyonu denenmiş ve umut verici sonuçlar rapor edilmiştir [15]. Shah ve arkadaşları, NPH tip B'de hemopoetik kök hücre naklini başarıyla uyguladıklarını bildirmişlerdir [16]. Tip B hastalarının beklenen yaşam süreleri adölesan ve genç erişkin yaşlardır. Tip B hastalarının tedavisi için gelecekteki beklentiler, enzim replasman ve gen tedavileridir. Enzim replasman tedavisi faz 2 düzeyindedir ve çalışmalar devam etmektedir $[1,4,6]$. Niemann-Pick tip C hastalığ 1 için substrat reduksiyon tedavisi ülkemizde de uygulanmaktadır. Tip C hastalarında miglustat kullanımının nörolojik hastalığın ilerlemesi üzerinde etkili olduğu gösterilmiştir $[17,18]$. Olgularımızın her ikisi de destek tedavileri ile izleme alındılar.

Sonuç olarak, hepatosplenomegali ile başvuran çocuklarda, karaciğer ve dalak özellikle sert palpe ediliyorsa, ülkemizdeki akraba evliliklerinin fazlalığı da dikkate alınarak, depo hastalıkları mutlaka düşünülmeli ve tanıya yönelik dikkatli bir kemik iliği incelemesi yapılmalıdır.

\section{Kaynaklar}

1. Schuchman EH. The pathogenesis and treatment of acid sphingomyelinase-deficient Niemann-Pick disease. J Inherit Metab Dis 2007; 30: 654-63. doi: 10.1007/s10545-007-0632-9.

2. Wasserstein MP, Desnick RJ, Schuchman EH, et al. The natural history of type B Niemann-Pick disease: results from a 10-year longitudinal study. Pediatrics 2004; 114: 672-7. doi: 10.1542/ peds.2004.0887.

3. Crocker AC, Farber S. Niemann-Pick disease: a review of eighteen patients. Medicine (Baltimore). 1958; 37:1-5.

4. McGovern MM, Desnick RJ. Defects in metabolism of lipids; Lipidoses (Lyposomal Storage Disorders). In: Kliegman RM, Stanton BF, St.Geme JW, Schor NF, Behrman RE, editors. Nelson Textbook of Pediatrics. 19th ed. Philadelphia: WB Saunders Company, 2011: 488.

5. Chang TY, Reid PC, Sugii S, Ohgami N, Cruz JC, Chang CC. Niemann-Pick type $\mathrm{C}$ disease and intracellular cholesterol trafficking. J Biol Chem 2005; 280: 20917-20. doi: 10.1074/jbcR4000040200.

6. Vanier MT. Niemann-Pick diseases. Handb Clin Neurol 2013;113:1717-21. doi: 10.1016/B978-0-444-59565-2.00041-1.

7. Mussig K, Harzer K, Mayrhofer H, Krageloh-Mann I, Haring HU, Machicao F. Clinical findings in Niemann-Pick disease type B. Intern Med J 2006; 36: 135-6. doi: 10.1111/j.1445-5994.2004.01013.x.

8. McGovern MM, Lippa N, Bagiella E, Schuchman EH, Desnick RJ, Wasserstein MP. Morbidity and mortality in type B Niemann-Pick disease. Genet Med 2013;15:618-23. doi: 10.1038/gim.2013.4.

9. McGovern MM, Pohl-Worgall T, Deckelbaum RJ, et al. Lipid abnormalities in children with types A and B Niemann Pick disease. J Pediatr 2004; 145: 77-81. doi: 10.1016/j.jpeds.2004.02.048).

10. Verot L, Chikh K, Freydiere E, Honore R, Vanier MT, Millat G. Niemann-Pick C disease: functional characterization of three NPC2 mutations and clinical and molecular update on patients with NPC2. Clin Genet 2007; 71: 320-30. doi: 10.1111/j.1399. 0004.2007. 00782.x.

11. Wasserstein MP, Larkin AE, Glass RB, Schuchman EH, Desnick RJ, Mc Govern MM. Growth restriction in children with type B Niemann-Pick disease. J Pediatr 2003; 142: 424-8. doi: 10.1067/ mpd.2003.113.

12. McGovern MM, Wasserstein MP, Aron A, Desnick RJ, Schuchman EH, Brodie SE. Ocular manifestations of Niemann-Pick disease type B. Ophtalmotalogy 2004; 111: 1424-7. doi: 10.1016/j. ophtha.2003.10.034

13. Suzuki O, Abe M. Secondary sea-blue histiocytosis derived from Niemann-Pick disease. J Clin Exp Hematop 2007; 47: 19-21. doi: 10.3960/jslrt.47.19.

14. Mendelson DS, Wasserstein MP, Desnick RJ, et al. Type B NiemannPick disease: findings at chest radiography, thin-section CT, and pulmonary function testing. Radiology 2006; 238: 339-45. doi: 10.1148/radiol. 2381041696.

15. Victor S, Coulter JB, Besley GT, et al. Niemann-Pick disease: sixteen-year follow-up of allogeneic bone marrow transplantation in a type B variant. J Inherit Metab Dis 2003; 26: 775-85.

16. Shah AJ, Kapoor N, Crooks GM, et al. Successful hematopoietic stem cell transplantation for Niemann-Pick disease type B. Pediatrics 2005; 116: 1022-5. doi: 10.1542/peds.2005-0867.

17. Ginocchio VM, D'Amico A, Bertini E, et al. Efficacy of miglustat in Niemann-Pick C disease: A single centre experience. Mol Genet Metab 2013;110:329-35. doi:pii: S1096-7192(13)00267-9. 10.1016/ j.ymgme.2013.07.019.

18. Pineda M, Wraith JE, Mengel E, et al. Miglustat in patients with Niemann-Pick disease Type C (NP-C): a multicenter observational retrospective cohort study. Mol Genet Metab 2009; 98: 243-9. doi: 10.1016/j.ymgme.2009.07.003. 